\title{
Teaching Inside The Box (Required College Teacher Preparation)
}

\author{
Mary Kennedy Minter, Ed. D., Education Consultant, USA
}

\section{PROPOSITION FOR CHANGE}

The contention for this paper is: that all doctoral programs should include a required twosemester teaching methodology and practice course for those who plan on university teaching as a career.

Keywords: Proposal for required college teacher preparation to improve classroom instruction.

\section{NEED FOR CHANGE}

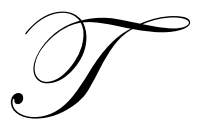

he reason this paper is entitled "Teaching INSIDE the Box" is not just meant for a play on words regarding a current trend to "thinking outside the box." It is meant in a much more literal sense. Consider this scenario: You are a new Ph.D. who decided to go straight through your education to complete a graduate program. At a minimum, you have probably spent an average of four years in undergraduate school, two years to acquire a master's degree and perhaps three years to complete the doctorate, including the writing of the dissertation. Therefore, you have invested at least a total of nine years obtaining education and credentials that qualify you to teach in a college/university. You have never taught in a classroom before. You are nervous about the assignments and overwhelmed when you go through the university's orientation. Fortunately, the department has a required syllabus format for you to follow and you stumble through setting that up to correspond with a brand new textbook with which you are not familiar. The first semester may be a disaster. You may be faced with a large class for a basic course in which there is an auditorium full of 100-150 students. You may or may not have a graduate assistant assigned to help you. You may have to teach a small class of only 10 or fewer students and that contrast can be just as overwhelming because of the change needed for assignments and interactions.

The point of this scenario is that, as a new assistant professor, you are going to have to "think and teach WITHIN the box;" that is., you are responsible for the teaching and student learning within the four walls of that classroom, "the box." What are you going to do with that responsibility? How are you going to teach and how will you know if your approach and results of teaching are successful? This is just part of why teacher training is necessary.

University teaching, which places the development of minds in the hands of neophyte teachers, is one of the few professions that does not require certified experience. That is, teacher training and certification should be required before one is allowed to practice "in the black box of university education." For example, would you be willing to have a newly graduated doctor perform brain surgery on you without knowing if she/he has had supervised and lengthy practice and experience in such surgery? The point is that a requirement for new professor teacher training would be comparable to a probationary period utilized in many other professional certification/license programs.

Another need for required college teacher training for new professors is that many of the disciplinary accrediting agencies are requiring AOL (assurance of learning) standards and documentation. How can these standards be reached and the results proven if there is a lack of knowledge and skills about the PROCESS of teaching that leads to the results?

In the author's opinion, it seems ironic that accrediting agencies are requiring proof of output results (student learning) while ignoring the important input factors. That is, if one views "teaching within the classroom" 
(teaching inside the box) from an open system concept, the conclusion appears logical. The key components of the open system concept are: "input, process, output, permeable boundaries, and feedback." This paradigm has been used for many years to help explain the dynamics of an organism (organization), its input, process, and results. ${ }^{1}$

From a 1990's viewpoint, Peter Senge emphasized that the art and practice of viewing organizations (e.g., the classroom environment) as an open system necessitates a shift of mind (metanoia) by acquiring the attitude that organizations are continually learning (changing). Senge proposed that the open system model allows the "seeing of the forest and the trees," that is, it provides a wide-angle lens that can view the larger dimensions and still capture the details. ${ }^{2}$

At the very least, the open system model should support the need for an organized, practicum in teacher training for the new college professor. Why? Because the open system concept illustrates the complexity of the communication/learning process involved in college teaching. It considers the crucial states of the teaching dynamics which directly affect the RESULTS that need to be assessed, that is, assessment of learning (AOL). The caveats, of course, are: (1) IF the input material (teacher and student) is not of high quality, (2) IF the process (resource conversion) is not competently facilitated, (3) IF the permeable boundary factors are uncontrollable or insurmountable, THEN the output (results) of the teaching/learning process may not meet quality standards.

\section{IDEAL PLAN FOR CHANGE}

The ideal plan would be to incorporate required college classroom teaching methods and practice into doctoral programs, no matter what subject matter is being studied. For example, each graduate student would be required to take one semester of teaching methodology (pedagogy) with several mini-teaching assignments and one semester of "student teaching" in an actual classroom where the graduate student is responsible for all professor duties. This student teaching would be under the supervision of a seasoned full-time professor or educational teacher-specialist.

Teacher training, regardless of discipline, should be mandatory even though the graduate student insists that he/she is not going to be teaching in a university/college. Why? Even if the graduate student believes that he/she never intends to teach in a classroom, the knowledge and skills learned in this teaching requirement can be invaluable to a research-oriented or business career. Researchers or business operatives will be faced with communicating instructions and ideas to many levels of constituents/stakeholders. They will simultaneously face challenges of persuasion, detailed explanation, evaluation, decision-making, coaching, etc. These are just a few of the same roles needed by a college classroom teacher.

\section{CONTINGENCY PLAN FOR COLLEGE TEACHER PREPARATION}

However, knowing the political, economical, and slow-changing manner of doctoral graduate programs and policies in this country, the bold contention described above needs a contingency plan. The alternative proposal is: the professorial representative and/or accrediting agencies need to step up and require universities and colleges to institute a minimum of two semesters of teacher training, during the first year of teaching for new professors. The first semester would include a required course in teaching pedagogy and methods. The second semester would include required monitoring and coaching of new professors' classroom performance. This process needs to be followed with monitoring and coaching during the second year of teaching. The new professor requirements would be comparable to a probationary period utilized in many other professional certification/licensed programs.

Topics recommended in this paper can be used as the basis for the first semester, required in-service teacher training. In essence, academic professional agencies need to be serving a quality control function in order to improve the basic quality of college classroom instruction and applied pedagogy. 


\section{Plan: Suggested, Basic Topics And Tasks For Required College Teacher, On-The-Job Training}

Basic topics for a "college teacher training," semester course are referenced below. These sample topic/tasks were developed by the author over twenty years of experimentation and practice in courses related to teacher training.

Recommended starting points for in-service topics are:

- $\quad$ Establishing course goals and objectives

- $\quad$ The first day: making content and expectations clear (designing the syllabus)

- $\quad$ Planning the lesson (daily class planning)

- $\quad$ Planning instruction for higher levels of thought (the Bloom's Hierarchy of thinking)

- $\quad$ Cultural Communication (including the need for clarity in English communication)

- $\quad$ Assessing Evaluation Methods (testing) and Assurance of Learning Measures

- $\quad$ Managing Group Discussion ${ }^{3}$

Topic-- Orientation for Teacher Training Course:

First, there is a need to clarify for the new teacher-professors that there are many roles which they will perform in their classroom teaching. The basics roles that are addressed in this one-semester teaching course are from the teacher's viewpoint (i.e., an instructor needs to assess in what functional roles she is engaged as she attempts to communicate her instruction to her students). These functional roles include, but are not limited to:

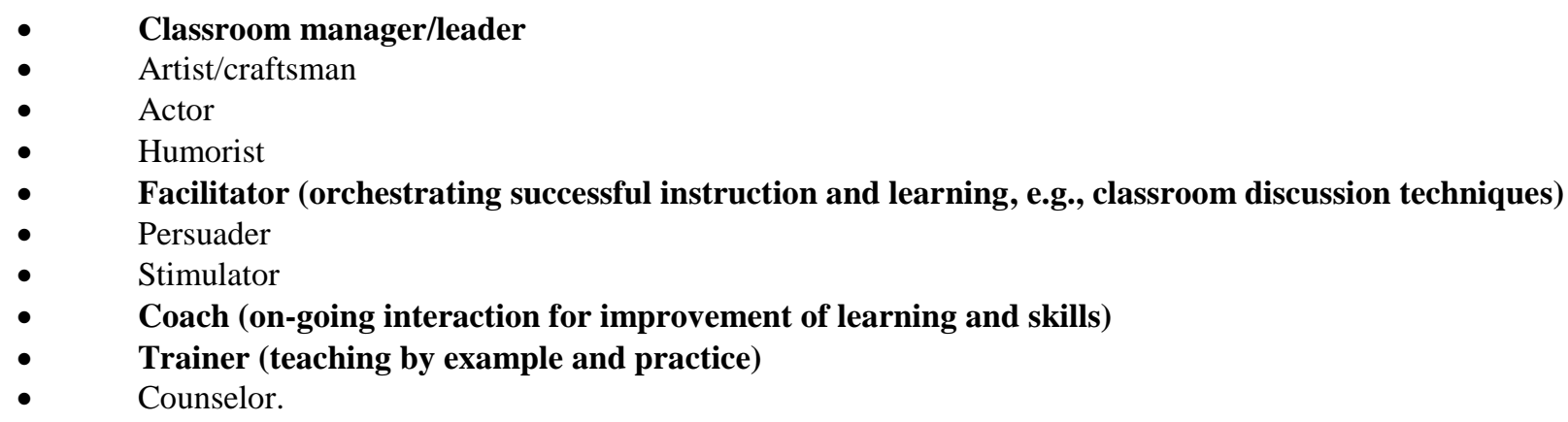

Notice that "lecturer" (information-giver) is not listed as a major role. It is this author's opinion that the lecturer method of teaching needs to be de-emphasized in order for substantive learning to take place. ${ }^{4}$

The roles that the author believes are most important have been highlighted in the list above. These are role-skills which should be emphasized in teacher training. That is, the new teachers will learn how to execute teaching within the parameters of these functional roles and be able to assess their performance by predetermined measures. This statement represents an example of a specific learning objective for the teacher training course.

One factor that should be emphasized in the orientation for teacher training is that such training is not just for teacher/professors, but also for any job positions in various kinds of business. The point is that no matter what career you are in, instruction will be a crucial part of your job. You will be called upon to manage, lead, facilitate, persuade, stimulate, coach, counsel, and train. The roles of artist, craftsman, actor, and humorist may be minor aptitudes and techniques, but having such skills can be "value added" and enhance your overall profile and effectiveness. The irony of this phenomenon of "roles we play in our jobs" is that training for instruction began when we were very young. For example, who taught you how to walk, talk, throw a ball, dance? How were you taught these basic skills? If you have children, chances are you taught them "how to tie their shoestrings" the same way you were taught as a child. An underlying implication to this "instructional phenomenon" is that we tend to teach the way we have been taught; hence, there is a propensity to continue teaching/instructing with a one-way communication model, i.e., the infamous "lecture method." 
Topic--Course Description, Goals, and Learning Objectives:

The emphasis in this college teacher training course should be on instructional communication methods and techniques in classroom, simulation assignments, self-assessments questionnaires, analysis, critical thinking through performance projects, classroom participation, and two (2) written reports. The format of this course is a LAB (performance course) in which student teachers will actively APPLY recommended methods and techniques of teaching.

\section{General Course Goals-}

Upon successful completion of this teacher training course, student teachers will demonstrate:

1. In writing and performance, workable knowledge and skills in instructional communication concepts: for example, in two written reports, students will define key terms and will relate communication concepts to real-life situations. These concepts originate in several fields of study, e.g., communication, education, business management theory/practice.

2. Effective public speaking skill in classroom performance through effective use of lesson plans (written documentation) and orchestrated performance (emphasis will be on student interaction, not straight lecture method).

3. Appropriate listening behavior during all speaking/teaching assignments. Effective listening skills involve responding appropriately to presentations by fellow student teachers, e.g., providing constructive feedback, displaying supportive behaviors during speaking performances, and documentation of results/reactions through journal entries.

\section{Example of a Specific Learning Objective:}

Before the complete presentation of her/his lesson unit (one-hour in length), the student teacher will have had practice in identifying and writing specific learning objectives within a standard format. This important preplanning function will be checked by the senior faculty facilitator (teacher trainer) by evaluating the student teacher's lesson plan before the person presents the lesson unit.

\section{Task--Self-assessment Inventories:}

It is recommended that several self-assessment inventories be given at the beginning of the course. These can be completed and scored outside of class and just the self-scored results can be discussed in class. Three very important inventories that have been used by author for many years are: Kolb Learning Style Inventory, ${ }^{5}$ a Listening Inventory, ${ }^{6}$ and Cognitive Style Inventory. ${ }^{7}$ It is important for the professor to recognize and be sensitive to how he/she learns in comparison and contrast to a student group profile. Based on the author's qualitative research, the majority of students perceive themselves as "active learners." The active learner description implies that "information-giving" only approach (the lecture) is NOT preferred by students. Then why do professors persist in the lecture-only approach, even if they "dress up" that lecture with a Power Point?

\section{Task--Self-Introductions:}

A very important initial assignment is for the new professors to introduce themselves. In this case, such an introduction will probably occur AFTER they have actually introduced themselves to all their classes. The facilitator can ask the new professor to approach this assignment by repeating (or having video-taped) what they did in their actual classes; then, after group comments, each new professor should be given the opportunity to repeat her/his self-introduction and improve upon it based on their colleagues' feedback.

It is important to emphasize to new professors that they have only 2-30 seconds to make that first impression that often remains in the mind of the student. The professors do not even have to say anything; it is how they are perceived by students. These perceptions are related to: how professors are dressed, how they conduct themselves before the class starts, how they enter the room, how they move and what their facial expressions show. 
All the non-verbal cues are there for the student audience, even before instructors open their mouths. Then, those first few words often say the most.

Task—Observing experienced professors:

New professors are to observe and write a journal entry on three (3) experienced professors in their department. A format is provided for the journal assignment that includes identifying: learning objectives, key communication factors, teacher style, and English competency (oral and written).

Task--Importance of frequent written feedback from students:

A feedback method that can be used frequently is referred to as the "Minute Paper." ${ }^{8}$ The facilitator of the teacher training course should use this feedback format, especially, for the first few class sessions, so that she can get a feel for how the new professors are relating to the teacher training course/process. Examples of quick-answer questions for this feedback paper could be:

1. What are your first impressions? -- of this course

-- of me, as your faculty facilitator

2. What did you learn from doing your "self-introduction"- the before and after version?

3. After our review of this course's syllabus, what other items/practice do you think should be included and why?

4. At this point of the course, do you think that this one-semester of teaching theory and practice will be beneficial to you? Why or why not?

5. Do you think the monitoring by your teacher facilitator during your second semester of teaching will be helpful to you? Why or why not?

Task--Impromptu Speaking on subjects selected by new professors (based on their own current teaching assignments, i.e., topics related to their own discipline):

New professors will select a topic related to their current teaching and discipline that can be explained and/or instructed within 10-15 minutes. This can be a topic that they have already presented/discussed in their own classrooms or perhaps better, one that they plan to do later in their classroom instruction. This is an opportunity for new professors to get feedback on their impromptu speaking instruction and they are required to use a "minute paper" feedback from their fellow new professors to get specific feedback on their performance. The presentations need to be videotaped and new professors are required to complete a self-evaluation before they complete another impromptu presentation.

During the first oral presentation, it will become very noticeable if any of the new professors have problems communicating in oral English. If that is the case, those professors should immediately be enrolled in private tutoring for "English as a Second Language." This instructional communication factor of new professors not being able to communicate effectively in English is a definite problem for English-speaking only students and can affect their learning of the subject matter being taught. This situation must be addressed by the total college/university administration and they must accept the responsibility of training foreign-speaking faculty in order to provide quality teaching. If the professor has been hired for her/his subject matter knowledge/skill expertise, the university will not be doing justice to the professor and/or students, if that professor cannot communicate effectively in the English language.

\section{Task-Two Written Reports (Essay format completed outside of class)}

The purpose (specific learning objective) of the written report is:

After completing the essays and having them evaluated by the faculty facilitator, the new professors will be able to recognize and correct one of a teacher's key responsibilities, i.e., the necessity of mechanical and grammatical writing skills demonstrated by both teachers and students. Point: How can we evaluate students on 
their "writing skills across disciplines" if the professor does not have these skills and can not correct the writing errors of students?

\section{SUMMARY}

The author has presented a plan, including basic topics, for a new college teacher training course to be implemented in the first year of teaching. In essence, this plan and recommended topics represent a simplified, operational framework on which to base a professional-oriented course, monitoring, and coaching for new college professors based on instructional communication skills and proven teaching methods.

\section{AUTHOR INFORMATION}

Mary Kennedy Minter, Ed.D., has been a college teacher for over 30 years and specializes in faculty development consulting. She has taught instructional and business/management communication at Texas Christian University, U. of Texas, Arlington, Texas Wesleyan University, University of Akron, and Cleveland State University.

Her degrees are: doctorate in Higher Education Administration, U. of Michigan; Master's degree in Organizational Communication/Industrial Relations from Purdue University; and Bachelor of Arts from Ohio University.

\section{Footnotes}

${ }^{1}$ Bertalanffy, L. von (1968). General system theory: Foundation, development, applications. New York: George Brazeller.

${ }^{2}$ Senge, P. M. (1990) The fifth discipline: The art and practice of the learning organization. New York: Doubleday. ${ }^{3}$ Minter, M.K. (January 2008). The College Teaching Methods \& Styles Journal (Vol. 4, No. 1). Littleton, CO: The Clute Institute for Academic Research.

${ }^{4}$ Minter, M. K. (2006), Instructional Communication Notebook (For Teacher Training). Fort Worth, TX: Texas Christian University.

${ }^{5}$ Kolb, David A. (1985). Learning-Style Inventory. Boston, MA: McBer and Company.

${ }^{6}$ Watson, K. W. \& Barker, L.L. (1995). Listening Styles Profile. San Francisco, CA: John Wiley \& Sons, Inc.

${ }^{7}$ Felder, R. M. \& Soloman, B.A. (2003). Learning Styles and Strategies. http://www.ncsu.edu/felderpublic/ILSdir/styles.htm

${ }^{8}$ Angelo, T. A. \& Cross, K. P. (1993). Classroom Assessment Techniques (2 ${ }^{\text {nd }}$ Ed.). San Francisco, CA: Jossey-Bass Publishers.

\section{REFERENCES}

1. $\quad$ Bain, Ken. (2004). What the Best College Teachers Do. Cambridge: Harvard University Press.

2. McKeachie, Wilbert James \& Svinicke, Marilla. (2005). McKeachie's Teaching Tips: Strategies, Research and Theory for College and University Teachers. Boston: Houghton Mifflin.

3. Mitchell, T. R. \& Larson, J. R. (1987) People in organizations: An introduction to Organizational behavior. ( $3^{\text {rd }} \mathrm{Ed}$.). New York: McGraw-Hill.

4. Seldin, Peter. (1995). Improving College Teaching. Anker Publishing Co., Inc. 